Article

\title{
Enhancing Urban Encounters: The Transformative Powers of Creative Integration Initiatives
}

\author{
Anniken Førde \\ Department of Social Sciences, UiT, The Arctic University of Norway, 9037 Troms $\varnothing$, Norway; E-Mail: anniken.forde@uit.no
}

Submitted: 10 August 2018 | Accepted: 22 October 2018 | Published: 24 January 2019

\begin{abstract}
Sustainable cites require the capacity to live with difference. In a world of increased mobility and migration, our cities become more and more diversified. While national discourses on diversity are often problem-focused, social initiatives are emerging in diverse cities addressing the positive potential of the city as a cross-cultural meeting place. In Norway, such initiatives have increased in number since "the refugee crisis" in 2015, and we see creative approaches arising from civil society, the voluntary sector, private companies, and local governments aiming to facilitate encounters with difference. This article explores innovative integration initiatives in cities in the north, emphasizing how difference might be negotiated, engendering new forms of engagement and responsibility. Cities are seen as sites of experiments, where new relations across difference are developed. Framing encounters as emergent, transitory, fragile, yet hopeful, we discuss the transformative powers of such initiatives for planning in diverse cities.
\end{abstract}

\section{Keywords}

collective learning; cross-cultural dialogues; encounter; Forum Theatre; integration; planning diversity; social initiatives; social innovation; situational understanding

\section{Issue}

This article is part of the issue "The Transformative Power of Urban Planning through Social Innovation", edited by Torill Nyseth (UiT, The Arctic University of Norway, Norway) and Abdelillah Hamdouch (University of Tours, France).

(C) 2019 by the author; licensee Cogitatio (Lisbon, Portugal). This article is licensed under a Creative Commons Attribution 4.0 International License (CC BY).

\section{Introduction}

In a world of increased migration and mobility, our cities become increasingly diversified. The dynamic complexity, diversity, and fluidity of contemporary cities pose challenges as well as opportunities for urban planning and policy-making. Cities are sites of multicultural belonging, and the cities' capacity to meet the needs of a diversified population and create social cohesion is crucial for sustainable urban development. While urban diversity includes a broad range of aspects, this study focuses on cultural diversity and the inclusion of immigrants. In the cities of Troms $\varnothing$ and Bod $\varnothing$, in Northern Norway, the numbers of immigrants have increased in recent years (of Troms $\varnothing$ 's population of 75,000, 14,1\% are foreign immigrants, as are $10,1 \%$ of Bod $\varnothing^{\prime}$ s population of 51,000 , according to Statistic Norway at www.ssb.no). Like in many other cities across Europe (Taşan-Kok, Bolt, Plüss,
\& Schenkel, 2017; Wilson, 2015), there are many emerging initiatives of welcoming new inhabitants and creating spaces for encounters across difference. However, along with initiatives addressing the positive potential of diverse cities, we see an increasing polarization in public discourses on migration and integration with drivers towards more exclusionary accounts of belonging. The "new urban condition", Wilson (2015) argues, is characterized by difference, fragmentation, and plurality, where drivers to tolerance and pluralization encounter their opposite. Cultural diversity is seen as an asset, but also as engendering fear. In Norway, immigration represents a necessary workforce and contribution to maintain population numbers and welfare services. At the same time, a lack of appropriate integration policy leads to increased social differences and processes of social as well as economic segregation (Aure, Førde, \& Magnussen, 2018). As Collier (2013) argues, migration has become politicized 
before it is analyzed. As European cities become ever more multicultural (Taşan-Kok et al., 2017), it becomes urgent to investigate the conditions for diversity as an asset. How can cities increase their capacity to live with difference? How do they plan for diversity and enhance encounters across difference? What are the transformative powers of innovative integration initiatives?

Planning has been criticized for failing to take account of the diversity of cities (Fincher \& Iveson, 2008; Quadeer, 1997; Sanderock, 1998). As noted by Campbell (1996), advocating social justice in urban planning is often met with other conflicting goals, such as promoting economic growth or the green city. Planners thus need new tools for staging inclusive processes and making the orientations of the negotiated plan real (Albrechts, 2004; Nyseth et al., 2017). By focusing on innovative integration initiatives, often initiated and performed outside of the formal planning systems, we seek to explore alternative ways of negotiating cultural difference. The challenge of living with difference and negotiating diversity has led to a growing concern for encounters in urban studies (Amin, 2012; Koefoed, Christensen, \& Simonsen, 2017; Valentine, 2008; Wilson \& Darling, 2016). This concern, however multifaceted, opens for a greater attention to complexities and contestations, and to the negotiation of difference. City life is often described by a sense of estrangement, of the being together of strangers (Ahmed, 2000; Amin, 2012; Sanderock, 2003; Young, 1990). As cities become more diverse, encounter across difference should be a goal for urban planning (Fincher \& Iveson, 2008). Is it possible to plan for encounters among strangers, and facilitate opportunities for positive experiences of diversity?

The socio-economic challenges introduced by globalization processes require innovation and experimentation in urban planning and development that are sensitive to shifting complexities (Nyseth et al., 2017). Social initiatives introduced and performed by various actorsoften in concert-seem to play a central role in creating spaces of cross-cultural encounter. In Bod $\varnothing$ and Troms $\varnothing$, numerous initiatives to create meeting places and interaction have emerged-especially since the increased arrival of refugees in 2015. Activities like language cafés, international women's networks, the "People's Kitchen", solidarity cafés, storytelling workshops, embroidery workshops, and various inclusive theatre, dance, and music events are some of the initiatives to be found in these cities. These initiatives stem from volunteer organizations, private companies or individuals, and the public sector, and often a mix of these. Many of them involve actors from the art and cultural industries. In the research project "Cit-egration-Sustainable Diverse Cities: Innovation in Integration" (financed by the Norwegian Research Council, 2017-2021), we study such social initiatives. By cultivating cross-cultural interaction, these initiatives seek to enhance shared belonging and positive coexistence. In order to understand their transformative powers, we need to understand how encounters take place and the impact of these spaces on everyday coexistence. As Wilson (2013) argues, there is little knowledge on which specific relations make such spaces productive. The aim of this article is to explore the potential of social initiatives to create spaces for cross-cultural interaction and dialogues. The article is structured as follows: first, we present theoretical reflections on planning for crosscultural encounters and methodological reflections on studying such encounters. Then we present two social initiatives: Forum Theatre in Bod $\varnothing$ and a storytelling workshop in Troms $\varnothing$. Based on experiences from these specific encounters, we discuss how new forms of engagement might be engendered, how difference might be negotiated, and how planning might facilitate such initiatives. The potential of integration initiatives is an emergent issue in contemporary urban transformation. Our point of departure is that urban planning should learn from these social initiatives and their experience of enhancing cross-cultural encounters. We argue that such initiatives are crucial to increasing the cities' capacity to live with difference.

\section{Theorizing Planning for Cross-Cultural Encounters}

The multicultural city is made of a multitude of encounters, where different trajectories, objects, and people form shifting compositions of thrown-togetherness, and multiple pasts and futures are folded into the present (Amin \& Thrift, 2002; Massey, 2005; Wilson \& Darling, 2016). Within work on urban diversity, the concept of encounter is widely used to explore spaces of cross-cultural interaction. However, the concept remains under-theorized (Wilson, 2017) and we still lack knowledge about how encounters are enacted and how they can contribute to trust and dialogue (Valentine, 2008). Encounter, Wilson and Darling (2016) argue, is centrally about the maintenance, production, and reworking of difference. Emphasizing the performative elements of encounter, the city is not seen as a site where existing differences meet. Encounter also has the ability to make and transform differences. Warning against a naïve celebration of urban inter-mingling, Valentine (2008) emphasizes that encounters do not necessarily lead to respect and trust. Encounters are embedded in history, material conditions, and power structures, and encounters with difference can produce conflicts and anxiety as well as acknowledgement and possibilities. Planning plays an important role in embracing hybridity, and Fincher and Iveson (2008) argue that facilitating encounters between people, similar and different, should be a core issue in urban planning. However, the dynamics of such inter-mingling are, and must always be, largely spontaneous and unpredictable. "Encounters with difference are emergent, often outside of expectation and complicate any neat accounts of agency, causality or moral cultivation" (Wilson, 2013, p. 76).

As the city becomes more diverse, there is a pressing need for approaches to planning and development that 
acknowledge the complexities of contemporary cities, emphasizing openness, temporality, and respect for differences (Hillier, 2007; Nyseth, 2011; Nyseth et al., 2017; Pløger, 2004). In her multiplanar theory, Hillier (2007) seeks to develop planning that is open for what might come-for the unknown. Criticizing planning for being too outcome-focused, and thus imposing a futile certainty on a contingent world, Hillier argues for a more flexible planning that is willing to compromise. Inspired by the French philosophers Deluze and Guattari, Hillier encourages an ontology of becoming that recognizes the dynamic complexities of time and space, and the importance of relations-as a politics of the possible. This involves a performance-based planning, a planning that makes sense of disorder and difference, dealing with an unpredictable future. We find these reflections on potential and becoming highly relevant for planning for diverse and just cities, where we argue that facilitating social innovation and cross-cultural dialogues should be central. Social innovation, understood as new ways of fostering inclusion and wellbeing through improving social relations, is becoming increasingly influential in research, collective action, and policy (Moulaert, MacCallum, \& Hillier, 2013). In emphasizing a better equilibrium in living together, social innovation explicitly refers to a position of social justice. In line with Moulaert et al. (2013), we argue that analyzing social innovation and planning for just diversity requires engagement with complexity and uncertainty. To plan for encounters among strangers necessarily involves planning for the (partly) unknown. In a study of planning for innovation in cultural industries, Førde and Kramvig (2017) demonstrate the challenges of planning for the unknown, of making planning and policy programs that are open to complexity and difference, which allows the presence of the non-present. It requires a relational perspective on innovation, planning, and encounter with emphasis on experimentation and improvisation. Experiments are speculative methods of knowing, working with doubt and uncertainty (Hillier, 2007; Nyseth et al., 2017). There is growing literature on experimental urbanism, where cities are seen as sites of experimentation. As Karvonen and van Heur (2014) demonstrate, these notions hold forth the promise of experimental processes and innovative action related to a range of fields, such as social cohesion. Concerning work on difference and multiculturalism, cities are often celebrated as laboratories for new social imaginaries and ways of belonging (Wilson, 2015). The urban is seen as a site for producing new forms of citizenship, cultural negotiation, and political interaction, and thus developing new modes of being, Wilson (2015) argues. The challenge is to develop planning approaches that are sensitive to social and cultural complexities, where social innovation and experimentation are key inputs. It implies giving up the fantasy of controlling the future, without giving up the responsibility of facilitating a better future (Hillier, 2007).

The issue of just cities in planning leans on Lefebvre's work of the right to the city (Fainstein, 2010; Fincher
\& Iveson, 2008; Lefebvre, 1996). The right to the city, Lefebvre (1996) claimed, implies the right to urban life of all those who inhabit the city, regardless of their cultural differences. Lefebvre claimed that social justice must involve certain rights to urban space, to participate in urban life, to use and shape the city as equals. If planning is about bringing imagined futures into being (Healey, 2010), we need to acknowledge the multiple imaginaries at play in diverse cities. Involving diverse groups in the planning process are crucial ideas in planning, but as Healey (2010) demonstrates, ideals of procedural fairness have proved hard to live up to. Many have argued that planners need to acknowledge their role in the politics of difference and engage in developing visions of the just city (Campbell, 1996; Fainstein, 2010; Fincher \& Iveson, 2008). Just diversity, Fincher and Iveson claim, requires a normative framework for planning practice going beyond matters of process. "To create more just cities, planners need a framework for making judgements between different claims in the planning process, as well as facilitating them" (Fincher \& Iveson, 2008 , p. 5). This implies that planners must engage with what is to be done, as well as how, with issues of substance and values as well as process. They suggest a set of progressive social logics; redistribution, recognition, and encounter.

In line with Fincher and Iveson (2008), we argue that the right to the city should also be understood as a right to encounter. Amin (2002) focuses on "micropublic" sites of compulsory daily interaction and conversation as spaces where diversity is accommodated. The right to encounter comprises daily or regular contact as well as more fluid meetings that occur unexpectedly in public spaces. The right to encounter further implies not only the right to be oneself, but also the right to "become someone else through exploratory encounters with the strangers with whom they share the same city" (Fincher \& Iveson, 2008, p. 13). When investigating cross-cultural encounters, it is important to avoid fixed categories of culture and belonging as these are constantly changed, in and through the encounters. As Wilson (2015) argues, there are different notions of belonging, sometimes in tension and sometimes in dialogue, continuously reconfiguring each other. It is also important to keep open the discussion on what "good encounters", "progressive diversity", or "the good city" might be. To call for creative approaches to planning which are sensitive to complexities and allowing for the unknown, and at the same time advertise for normative frameworks for just diversity is not an easy combination for urban planners. Arguing for planning as becoming, Hillier (2007) problematizes the normative role of planning, where the plan is a fixed statement of what ought to be. This should not be understood as discharging planners from the engagement in developing visions and norms for just and diverse cities. The notion of the urban laboratory is part of a wider discursive field including engaged research, interpreting urban development as a collaborative process that con- 
stitutes place-specific interventions. It thus connects to debates of the normative aims of social innovation, centering on processes of change, new practices, and concepts that connect future visions of cities to the "politics and practices of hope" (Karvonen \& van Heur, 2014; Moulaert et al., 2013). Facilitating encounters and hybridity and making it possible to adopt shared identifications across common divisions should be part of such a normative framework for urban planning and development.

\section{Methods: A Collaborative Approach}

Cross-cultural encounters are complex and fluid fields of study requiring methods that are sensitive to this complexity. As Wilson (2013) argues, it is important to attend to micro-contexts in relation to diversity-management and examine how new forms of engagement and responsibility might be engendered. In order to investigate how innovative integration initiatives can create spaces for cross-cultural interaction, and how planning can facilitate such initiatives, we must study how encounters across difference take place, and how they are conditioned.

This article is based on on-going research on innovation in integration in the cities of Bod $\varnothing$ and Troms $\varnothing$. The Cit-egration project is based on a collaborative approach, where we seek to co-produce knowledge with involved actors. Artists, voluntary organizations, and the municipalities are official and active partners of the project. The research team is following and taking part in a range of social initiatives, like theatre events, embroidery workshops, storytelling workshops, language cafés, and various city planning meetings and workshops. Our active role in the activities involves what Wilson (2013) calls observant participation as well as participant observation, which often demands the exploration of our own prejudices and comfort zones. Further, we have interviewed participants and collaborated with organizers in reflecting on the dynamics of the encounters; how difference is articulated and negotiated; how the events are planned and organized; and how they might lead to further interaction and participation in the city. We have also followed planning processes in these cities, participated at public meetings and events, and joined discussions and seminars with urban planners in Bod $\varnothing$ and Troms $\varnothing$, focusing especially on immigrants' participation-or lack thereof. In the Cit-egration project, case studies of innovative integration initiatives are combined with studies of how different groups in the city use urban space, how interaction transfer into participation and development of just cities, and the changing organizational pattern for voluntary work. Regarding the initiatives presented in this article, we have followed Forum Theatre and the storytelling workshop from the start, participated at workshops and events, had reflection dialogues with the organizers, and interviewed some of the participants. As we are taking an active role, and even initiating some of the activities, our research implies in- tervention. Far from being innocent techniques, our research practices produce not only different perspectives but also different realities (Law, 2004). Rather than aiming at order and unambiguity, Law argues that we need to find ways to deal with the messy realities of the worlds we are studying. This means not falling into the trap of (re)producing fixed categories, but striving to be sensitive to, and gain knowledge from, the emerging ambiguities and reconfigurations.

\section{Diversity as an Asset in Planning}

The inhabitants of Bod $\varnothing$ and Troms $\varnothing$ include people from many nationalities, more than 100 nationalities in $\operatorname{Bod} \varnothing$ (according to their website at bodo.kommune.no), and 136 in Troms $\varnothing$ (according to their website at tromso.kommune.no). Both cities have experienced increased asylum and refugee migration, family migration as well as labor and lifestyle migration. The largest groups of immigrants in Bod $\varnothing$ come from Poland, Somalia, Eritre, and Sweden, in Troms $\varnothing$ from Poland, Russia, Sweden, and Germany, with people from Poland and Syria representing the largest growing group. The regime of rights of different groups of immigrants provided them with different resources and possibilities.

Bod $\varnothing$ municipality stresses that diversity is an asset for the city and has worked to make refugees settle, emphasizing equal public services and facilitating immigrants' entrance into the labor market. In 2016, Bod $\varnothing$ was awarded by the Norwegian Directorate of Integration and Diversity for their work on settling refugees, and how perspectives on integration and diversity are included in the municipality's planning. In their planning strategy for 2016-2020, integration and diversity are accentuated as a common core in all plans and measures. Moreover, immigration is acknowledged as a crucial element in reaching the main objective of the municipal plan to increase Bodø's population to 70,000 by 2030 . Immigration and cultural diversity are emphasized as creating possibilities for industrial, cultural, and social development. The municipal plan aims to "create an urban community where diversity is a resource", to create meeting places and include immigrants in order to make them active citizens (Bodø Municipality, 2014, p. 25).

Troms $\varnothing$ 's municipal plan of being an inclusive and international city has been explicitly expressed. Troms $\varnothing$ also has a vision of increasing its population to 120,000 by 2044 (Troms $\varnothing$ Municipality, 2015), and here, reaching this goal depends on increased immigration. The municipality is currently working on a strategic plan for integration and has organized a series of café dialogues gathering public services in order to strengthen immigrants' participation in the labor market, education, and civil society. Troms $\varnothing$ municipality has established an integration board to make multiple voices heard in consultation procedures and to innovate the municipality's work on living conditions and participation (according to their website at tromso.kommune.no). 
Although integration and diversity are given priority in general municipal plans, the immigrant population is to a little extent included in actual planning processes. As cities of expansive growth, both Bod $\varnothing$ and Troms $\varnothing$ are developing new city districts and have many ongoing planning processes. Participation and experimental methods are emphasized. In Bod $\varnothing$ a city lab is launched to secure and energize citizens' participation in urban planning, and Troms $\varnothing$ has run numerous participatory workshops and experimental neighborhood festivals in recent years to involve the citizens in discussing the city's future. Still, few immigrants attend public meetings, the city lab, festival events, and other municipal initiatives to engage the citizens in participatory planning processes. In meetings with municipal planners in both cities, they express the need for new methods to involve a broader spectrum of the population. In addition, many of the immigrants we have met express a need for arenas to meet and participate in activities with other citizens across cultural backgrounds. Bringing together people and experience from the public authorities and administration, local industries, and the volunteer sector is an expressed aim in both cities' planning practices, and they are searching for ways to create spaces for these collaborative efforts. We argue that turning to innovative integration initiatives operating outside of planning processes, often by applying methods from the art and cultural sector, might offer useful insights on how cross-cultural dialogues might be facilitated.

\section{Creating Spaces for Cross-Cultural Interaction}

In this section, we will present two innovative integration initiatives. We have chosen the cases of the Forum Theatre in Bod $\varnothing$ and the storytelling workshop in Troms $\varnothing$ to illustrate how social initiatives within the cultural field might facilitate cross-cultural interaction, and to explore how difference is negotiated in specific encounters.

\subsection{Forum Theatre}

On a Wednesday morning, March 2018, a group of about 30 people is gathered at Folkets Hus, a public community house in Bod $\varnothing$ to perform Forum Theatre. The participants are immigrants, mainly from Syria and Ethiopia, and are relatively new to the city. With them is a theater instructor and three theatre actors, people from Batteriet, who organize these theatre events, and ustwo researchers following the project. The project is initiated and organized by Batteriet, a resource center under the volunteer organization The Church City Mission, working against social exclusion. The Forum Theatre project is financed by The Norwegian Directorate of Diversity and Integration, and is during the project period included as a part of these immigrants' obligatory introductory program, run by the municipality's refugee services. Batteriet has hired a theatre instructor and actors from Bod $\varnothing$ Amateur Theatre to lead the forum the- atres. The project started in January 2017 and runs for half a year with the same group. The group meets every second Wednesday to do forums on theatre plays, addressing different themes like democracy, borders, social control, how to get to know people in Bodø, and job interviews. This Wednesday the theme is connected to the MeToo campaign; the discussion is about acceptable and unacceptable ways of approaching someone you are interested in. The session starts, as always, with various exercises. Using our bodies as much as words, we explore each other's borders for intimacy and ways of greeting in different situations and cultures. Then, the theater ensemble performs a short play of a young male medical student who falls in love with his female tutor. As is always the case in these plays, it ends in a catastrophic situation; signals are misunderstood, the student inappropriately seduces his tutor. Then the play is repeated, but this time all participants can take part in changing the performance of the protagonist: the male student. "Stop!" shouts one participant after the other, every time someone wants the actor playing the student to do or say something differently, jumping up to replace him. With a great deal of engagement, bodily expression, noise, and laughter, every situation in the play is challenged and new solutions proposed.

Forum Theatre, devised by Augusto Boal and often described as Theatre of the Oppressed, is used internationally as a tool of empowerment (Day, 2002). It is used as a democratic method to increase participation and make multiple voices heard. The organizers of Forum Theatre in Bod $\varnothing$ see this method as particularly suited to face immigrants' situation, as it combines language and cultural training, creates new relations through interaction, and provides joyful breaks in the participants' "trapped situation of waiting" at the asylum center. The language used in the play is Norwegian, with some translation into English and Arab. However, even more communication is based on bodily expression. "It is a suitable arena for interaction when language is a great challenge. We create trust by using the body to initiate communication", one of the organizers argues. The theatre events are highly appreciated by the participants. An Eritrean participant explains: "We talk about the Norwegian society, which is very helpful. The themes are the real life that we are in. All the problems we are in". In addition to offering an arena for participatory language training, the participants stress the importance of the cultural training; the guidance towards trivial everyday situations such as how to meet people on the bus and how to greet neighbors. By presenting stereotyped plays of various situations and then opening the storyline for intervention, difference is articulated and contested. The theatre instructor emphasizes the importance of not presenting fixed solutions in the plays, but rather keeping them open for alternative interpretations and interventions. The Forum Theatre provides an arena for testing out different approaches to specific situations. 


\subsection{Storytelling Workshop}

In Troms $\varnothing$, February 2018, eight participants, one instructor, and two researchers are gathered at Rådstua, the house for performing arts, to join a storytelling workshop. The project is initiated by The Norwegian People's Aid, supported by the Cit-egration project, organized in collaboration with HATS-a regional interest group for performing arts, and led by a professional theatre actor from SadioNor Theatre Company. Over four evenings, the participants will work on preparing and performing stories from their own lives, ending in a public storytelling event two months later. The participants differ in age and cultural background. They come from Norway, Syria, Ethiopia, Ukraine, and Peru. The youngest are in their $20 \mathrm{~s}$ and the oldest are in their $80 \mathrm{~s}$. They are recruited through HATS. Some have experience in storytelling and performing, others do not. We start with exercises focusing on how to use our voice. Then we all sit together in a circle and share short stories from our lives, like "tell of a moment when you were really afraid". For the next sessions, the eight participants work on stories they are to perform on the final public storytelling event. The only task they are given is to tell something from their life. Then they receive instruction and help from the actor, in a group and individually, on how to frame and dramatize their stories.

Through short accounts of joy and fear, the storytellers share life experiences and get to know each other. They attune their own stories to the life experiences of the others. After being inspired by stories of being on the run from the Syrian army and an authoritarian regime in Ethiopia, an elderly man from Northern Norway decided to tell his story of being a refugee in his own country during the Second World War. By telling a poetic story of his late dog, an Ethiopian man also expresses how difficult it can be to make friends in Norway. For some participants, the storytelling event was the first time they spoke Norwegian in public. By sharing dramatic experiences from before they came to Norway, they also got to mediate parts of their life stories to their friends and others joining the public event. As a woman from Peru expressed: "We who are immigrants are always vulnerable. We miss our home countries. We have so much to tell about our countries, and we would so much like to be heard". The storytelling event became a rare and important occasion, offering professional training and an audience. Another participant, also from Northern Norway, decided to tell the story of how she came to acknowledge and embrace her long-denied Saami identity. A month after the event, she explained how hard it was to articulate these ambiguous feelings of belonging, and how the sharing of stories across difference throughout the workshop enabled her story to be told: "It took time to tell this story, to get the courage. We gave each other courage".

The concept of the storytelling workshops, the instructor explains, is simple: "A story from your life is unique. And we will listen to you". It was not his plan that the stories should affect the participants' lives so much. In the workshops, differences are articulated and used as sources of inspiration. The way the participants connect and attune to each other, differences in age and background are bridged and the shared elements of very different life stories come to the fore. When the group gathered a month after the event, they decided to take the experiences further and initiated an association to create arenas for people to share their own stories. "This should be the beginning of a movement", one of them says, claiming that such sharing of stories provides courage and hope.

\section{Negotiating Difference}

Initiatives like these offer spaces of encounter by bringing together urban dwellers from diverse backgrounds in joint activities. As demonstrated also by others (Taşan-Kok et al., 2017), being united around a shared activity may bridge differences in ethnic, class, or cultural background. Through active participation, engagement is mobilized. Participants at the storytelling workshop emphasize that they get to tell stories from their lives that have never been told before and that they have the opportunity to relate to others' stories they would otherwise never have access to. By sharing experiences, mutual understanding and appreciation are engendered. By doing theatre exercises or telling stories together, a kind of conviviality is created where diverse individuals can work together on shared activities that do not reduce them to fixed identity categories.

In these encounters, differences are articulated, negotiated, and contested. The Forum play, when the participants get into an engaged dispute about how the male student should behave towards his female tutor, serves as an example. These negotiations, often performed through humor and laughter, hold multiple layers of meaning. By testing out alternative interpretations of, and approaches to, specific hypothetical situations, they negotiate values and norms. They compare incongruent approaches and try to work out how to relate across the differences. This way of staging hypothetical cultural clashes always holds a risk of producing or reinforcing cultural stereotypes. Boundaries can be produced as well as dispersed in encounters. Being aware of this, the organizers constantly discuss whose stories they play, trying to open up for nuancing the characters in the play. However, as one of the actors says: "We strive to create an arena for interaction among equals, but it is not that simple. The immigrants do not feel as safe as we do, feel like equals".

Both participants and organizers of these initiatives emphasize the importance of "the here and now" in these encounters, of the experiences they share, where their life situation outside of that room and its fixed identities and hierarchical lines are put aside-if only for a while. The value of these moments of community should not be underestimated. Nevertheless, there is lit- 
tle doubt that these encounters resonate beyond their own immediate events. As Wilson and Darling (2016) argue, such encounters might contribute to shaping opinions and future competencies for encounter. Our study confirms this, through the participants' accounts of how taking part in the storytelling workshop has given them the courage to tell their stories, and how participating in Forum Theatre has made it easier for the immigrants to interact with Norwegians-in Norwegian, and vice versa. New relations are created through this participation across cultural backgrounds. The initiators of these initiatives, Batteriet, Norwegian People's Aid, and their collaborative partners see these projects as part of the wider work of integrating immigrants with the city, of providing language and cultural training, of creating mutual understanding and relations. Especially the Forum Theatre, which is part of the obligatory introduction program for refugees, has an introduction to work, education, and civic participation as a core aspect. The Directorate for Integration and Diversity, which is financing the project, has contributed to defining the themes for the forum plays, where participation is a common core subject. For some of the participants, participating in these encounters has become a doorway to broader participation in the city. By creating a new association, the participants of the storytelling workshop continue and expand their network of storytellers in Troms $\varnothing$. In $\operatorname{Bod} \varnothing$, several of the Forum Theatre participants have been encouraged into voluntary work with sports clubs and other activities in the city.

These initiatives are not directly linked to planning processes in the cities. They operate outside of the municipal planning structures and practices, with other aims and methods. We argue that these initiatives are highly relevant for planning just and diverse cities, as they contribute to new city dialogues. With methods that allow fixed, predefined identities and power structures to be put aside; they enable the broader participation that is often missing in planning processes. Allowing negotiation of different belongings, needs, and imaginaries, they contribute to condition new imaginaries of urban futures-taking into account the complex and shifting thrown-togetherness of contemporary cities.

\section{Planning Social Initiatives}

Planning for new and established inhabitants to meet and interact is far from straightforward, as it requires complex work of cultural translation and enters into multiple power geometries (Aure et al., 2018). Immigrants are often people on the move, creating a shifting and fluid field for integration initiatives. The initiative organizers stress the unpredictability characterizing such activities on many levels. In Forum Theatre, the group varies from time to time due to turnover at the asylum center. New ones arrive and others disappear-some are deported, others are given permission to settle in Norway and are transferred to other municipalities. This makes it difficult to plan; the organizers constantly have to change their program and expand their repertoire. Thus, keeping an open space for the unpredictable in planning the workshops and events becomes crucial. Financed by the national integration authorities, the Forum Theatre has to deliver on a project design with pre-defined themes. The theater ensemble claims this works against the principles of Forum Theatre, which is to base the plays on the participants' stories. However, initiatives such as these require resources, and often depend on public financing. "It is difficult to get financial support for projects that are hard to quantify", the initiator of Forum Theatre explains. They constantly have to balance the need to predefine outcomes in project applications against the need for allowing collective improvisation.

These initiatives are innovative as they develop creative approaches to cross-cultural interaction, working towards partly unknown outcomes. Planning such initiatives is challenging, as any design to some extent demands the unpredictable being designed out (Førde \& Kramvig, 2017). However, encounters cannot be reduced to the planned or designed outcome. These initiatives are interventions designed to encourage people to meet and interact, but also to think differently about themselves, each other, and their city. The direct and ripple effects of such encounters will often be hard to define and thereby evaluate. Facilitating creativity in this field thus requires plans and programs allowing the unknown to appear. Here, the contributions from art and cultural industries might offer significant insights, as the ongoing unknown, the appearance of the non-present, is a central part of their work. The actors organizing theater and storytelling events work in ways that demand not only improvisation and flexibility, but also planning. Through creative experimentation, these initiatives offer imaginative horizons. We argue that they also offer working methods that could inspire and inform planning for just and diverse cities.

To argue for the importance of facilitating social initiatives like these is not to ignore the importance of mainstreaming in diversity management and planning. As demonstrated by Hou and Kinoshita (2007), more informal social interaction complements formal processes in navigating and overcoming social and cultural differences in communities, particularly between old-timers and newcomers. A just and diverse city needs encounters of different kinds and temporalities. Successful spaces of encounter encourage planned as well as spontaneous meetings (Taşan-Kok et al., 2017). Diversity management thus requires planning for encounter that acknowledges and supports the necessary spontaneity for new crosscultural dialogues and relations to emerge.

\section{Conclusion}

Northern cities have always been diverse, but cultural diversity is increasing. Social cohesion and social innovation have become key inputs in sustainable urban plan- 
ning and development (Nyseth et al., 2017). In this article, we have shown how innovative integration initiatives connecting urban dwellers with diverse backgrounds might contribute to new urban encounters, enhancing interaction and dialogue across cultural differences. The many social initiatives provide spaces to explore and negotiate difference-and to go beyond them. By offering spaces for people to interact across fixed identities of belonging, we argue that these encounters hold the potential for creating new senses of identity and belonging. Further, such encounters present a possibility to challenge the often problem-focused national discourses, emphasizing the positive potential of the city as a cross-cultural meeting place. Through spaces of intermingling, city dwellers become familiar with diversity, which again contributes to reduce fear and anxiety, making people feel safer in the multicultural city. Crosscultural encounters thus offer the possibility to transform difference.

Enabling interaction and dialogue across difference is momentous in planning for just and diverse cities. It is important that local authorities support social initiatives enhancing cross-cultural encounters, but also provide the necessary flexibility to form projects based on particular and shifting contexts and improvise when needed. Many such initiatives involve art and cultural industries. We argue that their approach to working and dealing with the hybridity and unpredictability characterizing meetings of strangers, offer important insights for planning and development in diverse cities. Through creative experimentation, bringing in a multiplicity of imaginaries, new imaginative horizons can be created. As McFarlane (2016) argues, encounter offers a lens onto both the city that already exists and the city that might become something different, through an engagement with both its future and its past. Although fragile and transitory, the crosscultural encounters created by, and through, social initiatives are promising. They may play a role in shaping the politics of the city, and who gets to be a part of that story. By learning from these initiatives and encounters, we might be able to enact difference differently in the city.

\section{Acknowledgments}

This article is part of the research project "Cit-egrationSustainable Diverse Cities: Innovation in Integration" funded by the Norwegian Research Council. Ideas are developed in collaboration with my fellow researchers in the project: Marit Aure and Torill Nyseth at UiT-The Arctic University of Norway, Tone Magnussen, Nordland Research Institute, and Gregory Taff, NIBIO. I would like to thank Norwegian Peoples Aid SørTroms $\varnothing$ ya, Batteriet, HATS, SadioNor Theatre Company, and all the participants at the events. I would also like to thank the editors and the reviewers for their constructive comments. The publication charges for this article have been funded by a grant from the publication fund at UiT-The Arctic University of Norway.

\section{Conflict of Interests}

The author declares no conflict of interests.

\section{References}

Ahmed, A. (2000). Strange encounters. Embodied others in post-coloniality. London: Routledge.

Albrechts, L. (2004). Strategic (spatial) planning reexamined. Environment and Planning B, 31(5), 743-758.

Amin, A. (2002). Ethnicity and the multicultural city: Living with diversity. Environment and Planning A, 34(6), 959-980.

Amin, A. (2012). Land of strangers. Cambridge: Polity Press.

Amin, A., \& Thrift, N. (2002). Cities: Reimagining the urban. Cambridge: Polity Press.

Aure, M., Førde, A., \& Magnussen, T. (2018). Will migrant workers rescue rural regions? Challenges of creating stability through mobility. Journal of Rural Studies, $60,52-59$.

Campbell, S. (1996). Green cities, growing cities, just cities? Urban planning and the contradictions of sustainable development. Journal of the American Planning Association, 66(1), 296-312.

Bodø Municipality. (2014). Kommuneplan 2014-2026. Strategisk samfunnsdel Bodø 2030 [Municipal plan 2014-2026. Strategic social part of the municipal master plan Bod $\varnothing 2030]$. Bod $\varnothing$ : Bod $\varnothing$ Municipality.

Collier, P. (2013). Exodus. How migration is changing our world. Oxford: Oxford University Press.

Day, L. (2002). 'Putting yourself in other peoples' shoes': The use of Forum Theatre to explore refugee and homeless issues in school. Journal of Moral Education, 3(1), 21-34.

Fainstein, S. (2010). The just city. New York, NY: Cornell University Press.

Fincher, R., \& Iveson, K. (2008). Planning with diversity in the city. Redistribution, recognition and encounter. Hampshire: Palgrave Macmillan.

Førde, A., \& Kramvig, B. (2017). Cultural industries as a base for local development: The challenge of planning for the unknown. In A. Hamdouch, T. Nyseth, C. Demazière, A. Førde, J. Serrano, \& N. Aarsæther (Eds.), Creative approaches to planning and local development. Insights from small and medium-sized towns in Europe (pp. 81-96). Oxon: Routledge.

Healey, P. (2010). Making better places. The planning project in the twenty-first century. Hampshire: Palgrave Macmillan.

Hillier, J. (2007). Stretching beyond the Horizon: A multiplanar theory of spatial planning and governance. Aldershot: Ashgate.

Hou, J., \& Kinoshita, I. (2007). Bridging community differences through informal processes: Reexamining participatory planning in Seattle and Matsudo. Journal of Planning Education and Research, 26(3), 301-314. Karvonen, A., \& van Heur, B. (2014). Urban laboratories: 
Experiments in reworking cities. International Journal of Urban and Regional Research, 38(2), 379-392.

Koefoed, L., Christensen, M. D., \& Simonsen, K. (2017). Mobile encounters: Bus $5 A$ as across-cultural meeting place. Roskilde: Mobilities.

Law, J. (2004). After method: Mess in social science research. Abingdon: Routledge.

Lefebvre, H. (1996). Writings on cities. Oxford: Blackwell.

Massey, D. (2005). For space. London: Sage.

McFarlane, C. (2016). Encountering what is (not) there. In J. Darling \& H. Wilson (Eds.), Encountering the city. Urban encounters from Accra to New York (pp. 229-232). Oxon: Routeledge.

Moulaert, F., MacCallum, M., \& Hillier, J. (2013), Social innovation: Intuition, precept, concept, theory and practice. In F. Moulaert, D. MacCallum, A. Mehmood \& A. Hamdouch (Eds.), The international handbook on social innovation. Collective action, social learning and transdisciplinary research. Cheltenham: Edward Elgar Publishing.

Nyseth, T. (2011). The Troms $\varnothing$ experiment: Opening up for the unknown. Town Planning Review, 82(5), 573-593.

Nyseth, T., Hamdouch, A., Demazière, C., Aarsæther, N., Førde, A., \& Serrano, J. (2017). Perspectives on creative planning and local development in small and medium sized towns. In A. Hamdouch, T. Nyseth, C. Demazière, A. Førde, J. Serrano, \& N. Aarsæther (Eds.), Creative approaches to planning and local development. Insights from small and medium-sized towns in Europe (pp. 13-21). Oxon: Routledge.

Pløger, J. (2004). Strife-Urban planning agonism. Planning Theory, 3(1), 71-92.
Quadeer, M. A. (1997). Pluralistic planning for multicultural cities: The Canadian practice. Journal of American Planning Association, 63(4), 481-494.

Sanderock, L. (1998). Making the invisible visible: A multicultural planning history. Berkley, CA: University of California Press.

Sanderock, L. (2003). Cosmopolis II: Mongrel cities of the 21st century. London: Continuum.

Taşan-Kok, T., Bolt, G., Plüss, L., \& Schenkel, W. (2017). A handbook for governing hyper-diverse cities. Utrecht: Utrecht University, Faculty of Geosciences.

Troms $\varnothing$ Municipality. (2015). Kommuneplanens samfunnsdel 2015-2026 [The social part of the municipality master plan 2015-2026]. Troms $\varnothing$ : Troms $\varnothing$ Municipality.

Valentine, G. (2008). Living with difference: Reflections on geographies of encounter. Progress in Human Geography, 32, 323-337.

Wilson, H. (2013). Learning to think differently: Diversity training and the 'good encounter'. Geoforum, 45, 73-82.

Wilson, H. (2015). An urban laboratory for the multicultural nation? Ethnicities, 15(4), 586-604.

Wilson, H. (2017). On geographies and encounter: Bodies, borders, and difference. Progress in Human Geography, 41(4), 451-471.

Wilson, H., \& Darling, J. (2016). The possibilities of encounter. In J. Darling \& H. Wilson (Eds.), Encountering the city. Urban encounters from Accra to New York (pp. 1-24). Oxon: Routledge.

Young, I. M. (1990). Justice and the politics of difference. Princeton, NJ: Princeton University Press.

\section{About the Author}

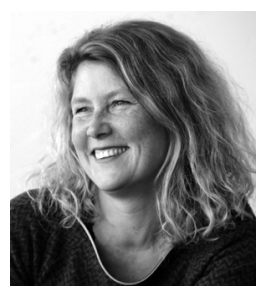

Anniken Førde is Associate Professor of Community Planning the Department of Social Sciences, UiT, The Arctic University of Norway. Her research interests include transformation processes of places, innovation policies and practices, especially within the creative industries, as well as planning for just diversity. She teaches philosophy of science and methodology for students in Community Planning and Cultural Studies and is interested in methodological issues related to the exploration of complex, relational realities. 